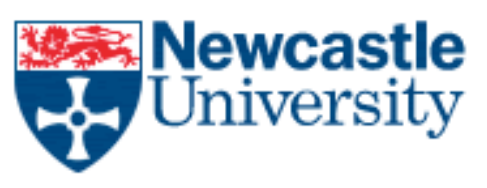

\title{
ePrints
}

\section{Pain R.}

Gendered violence: rotating intimacy.

Area 2014, 46, 351-353.

\section{Copyright:}

This is the peer reviewed version of the above article, which has been published in final form at https://doi.org/10.1111/area.12138 4. This article may be used for non-commercial purposes in accordance with Wiley Terms and Conditions for Self-Archiving.

Date deposited:

$19 / 12 / 2017$

Embargo release date:

17 November 2016 


\section{Gendered violence: rotating intimacy}

\section{Abstract}

This essay explores what the framing of intimacy-geopolitics as interwoven strands of a single structure means for gendered violence. It considers some longstanding and newer forms of violence that work through intimacy, and draws attention to the messy relation with resistance.

Key words: domestic violence, warfare, online violence, institutional violence

If feminist geography has a united project, it is turning the inside-out and the outside-in: making visible and central to social and spatial relations phenomena which are often framed as simplyintimate. In our introduction (Pain and Staeheli, this issue), we suggested that intimate relations and emotions are not only part of the connective tissue of relations that stretch across and between communities, cities, and states, but foundational to them. Here, I extend this framing to different forms of gendered violence.

Feminist scholarship has made it clear that gendered violences are linked across scales and sites (Moser 2001; Tickner 1992). In Frames of war, Butler (2010) charts the racialised hierarchies that determine which lives and whose suffering is recognised and deemed grievable by the West: these enable the cold rationality underpinning recent military interventions, skew media representations of victimhood, and feed the demonization of Muslims within the West (Razack 2008). Yet, as I have argued elsewhere, this distancing is also performed in relation to the violences that are closer to home, especially manifest in the social recognition of domestic violence (Pain 2014a). Forefronting the intimate in analysis of gendered violence - and simultaneously redefining intimacy as already present and woven through broader processes and sites - presents one way of recognising that all forms of gendered violence are, as feminists have maintained, part of the same complex of harm and control. 
For example, terrorism may comprise spectacular moments rather than long term entrapment, but like domestic abuse it achieves its work through control of emotions, particularly fear (Pain 2014a). Longstanding work by black feminists and feminist international relations scholars has connected international warfare and intimate violence, charting the use of rape in war, the rise in domestic abuse amongst military and civilian families during and after combat (INCITE! 2006), and the imperatives of hypermasculinity and masculinist protection in state conflicts as in intimate violence (Sjoberg 2013; Young 2003). Even in what is called peacetime, intimate violence has congruence with international conflict: its emotional dynamics and tactics strongly resonate with the conduct and psychology of warfare (Pain forthcoming). Aggressors pursue the enforcement of their worldviews, laying blame and justifying violence through carefully constructed ethical framings. The psychological occupation of domestic abuse, the mindgames played by perpetrators and Orwellian doublethink required for resilience resemble occupying forces' deployment of their intimate cultural knowledge of the people they oppress (see Marshall, this issue).

An important strand in the connective tissue of gendered violence is resistance. As we have suggested (see Pain and Staeheli, and other essays in this issue) resistance is never in straightforward opposition to violence, but exists in messy and dynamic relation, and may also be an intimate practice. In situations of domestic violence, resistance is necessarily private and small-scale, not always planned and strategic, but may be faltering and unanticipated. It does not always clearly work against the paralysing effects of violence and fear: some of the time, it works with them (Pain 2014b). When resistance is more publicly articulated, the response may be further aggression, as the emerging issue of online violence against women, particularly threats of sexual violence on Twitter and Facebook, illustrates. Threats made against women who oppose gendered violence often shatter the myth of any distinction between offline and online violence (Citron 2009); threats are intimate, and they have real life effects. Online violence is a reassertion of power, but perpetrators often deny this, minimising and de-scaling it, and drawing on a claim commonly made of older forms of gendered violence: that its spatial context means it is not-violence. These claims reflect how gendered violence is positioned within our culture at large (Women in Toronto Politics 2013; cf Dowler et al 2014). When we raise our heads to speak about violence - as individual victimsurvivors, as activists, as scholars - we often face the same exhortations that work in the interests of power.

Geographers have had a tendency to analyse violence at and from a distance, at the same time as we are part of the relations that sustain or challenge it (Pain forthcoming). Many of our institutions have historical connections to violent imperialism, are complicit in contemporary oppressive social 
and economic relations, and they are also everyday sites of intimate violence. As Dowler et al (2014) argue in their analysis of recent institutional cover-up of sexual assault at Penn State University, the neoliberal cultural economies of Universities and colleges have led them to prioritise institutional reputation over the welfare of individuals.

Whether targeted at men, women or children, gendered violence works through intimate control and fear at multiple scales. At all scales, too, the intersecting structures of gender, racism, ethnocentrism and class privilege frame who loses most (INCITE! 2006). Social attitudes and policy responses still reflect unawareness of the tense interface at which intimate violence might become public, and vice versa; always threatening, always precarious, its leakiness is full of risk. Yet the common separation of violences as significant (read: a social, political, global issue) or not, prevents the recognition of certain victims and the grievability of their suffering. Often, one form of violence compounds the effects of the other. Violence is a bouncing bomb, moving across intimacygeopolitics and gathering destructive power. If intimacy-geopolitics is a single complex, the challenge is to approach gendered violences together, and to rotate intimacy so that it becomes primary to understanding.

\section{References}

Butler J 2010 Frames of war: when is life grievable? London: Verso

Citron D K 2009 Law's expressive value in combating cyber gender violence Michigan Law Review $108373-416$

Dowler L, Cuomo D and Laliberte N 2014 Challenging 'The Penn State Way': a feminist response to institutional violence in higher education Gender, Place and Culture 213 387-394

INCITE! 2006 Color of violence: the INCITE! anthology South End Press, Cambridge MA

Moser C O N 2001 The gendered continuum of violence and conflict: an operational framework in C O N Moser and F C Clark eds Victims, perpetrators or actors? Gender, armed conflict and political violence London: Zed Books 30-51

Pain R 2014a Everyday terrorism: connecting domestic violence and global terrorism Progress in Human Geography 384 531-50

Pain R 2014b Seismologies of emotion: fear and activism during domestic violence Social and Cultural Geography 152 127-49 
Pain R forthcoming Intimate war Political Geography

Razack S H 2008 Casting out: the eviction of Muslims from Western law and politics University of Toronto Press: Toronto

Tickner J A 1992 Gender in international relations New York: Colombia University Press

Women In Toronto Politics 2013 The 7 deadly myths of online violence against women http://witopoli.com/2013/10/11/the-7-deadly-myths-of-online-violence-against-women/ (accessed 10 July 2014) 